\title{
Do temperature-food interactions matter? Responses of production and its components in the model heterotrophic flagellate Oxyrrhis marina
}

\author{
Susan A. Kimmance ${ }^{1,3}$, David Atkinson ${ }^{2}$, David J. S. Montagnes ${ }^{2, *}$ \\ ${ }^{1}$ Port Erin Marine Laboratory, University of Liverpool, Port Erin, Isle of Man IM9 6JA, British Isles \\ ${ }^{2}$ School of Biological Sciences, University of Liverpool, Biosciences Building, Crown Street, Liverpool L69 7ZB, UK \\ ${ }^{3}$ Present address: Plymouth Marine Laboratory, Prospect Place, Plymouth PL1 3DH, UK
}

\begin{abstract}
The consequence of interactions between temperature and food concentration for protistan population dynamics and estimates of aquatic productivity are relatively unknown, primarily because we lack adequate parameters for models. Here, using the heterotrophic flagellate Oxyrrhis marina Dujardin, we demonstrate the importance of considering temperature and food concentration in combination, to determine the responses of grazing rate, specific growth rate, cell volume, specific production and yield. Specific growth rate and cell volume responded in different ways to temperature-food concentrations: prey concentration had greatest positive effects on specific growth rate with increasing temperature, and prey concentration had greatest positive effects on cell volume with decreasing temperature. The effect of these contrasting interactions on specific production (=specific growth rate $\times$ cell carbon) was a greater response to prey concentration at intermediate temperatures. We also observed that the threshold food concentration for growth increased with increasing temperature, but yield showed no clear thermal response. By applying iterative curve-fitting to data obtained from multiple temperature-food concentration combinations, we produced phenomenological models of grazing rate, specific growth rate, and cell volume. We then compared predictions from a simple predator-prey simulation model that applied either our derived equations or a single exponential $\left(Q_{10}\right)$ relationship to the specific growth and ingestion responses at $20^{\circ} \mathrm{C}$. Considerable differences in predator and prey abundance were obtained between the 2 models. Our results demonstrate the potentially complex effects of food and temperature in combination on production parameters, and we argue that these should be considered in aquatic ecosystem simulation models.
\end{abstract}

KEY WORDS: Cell size $\cdot$ Ecosystem model $\cdot$ Functional response $\cdot$ Interaction $\cdot$ Microzooplankton · Numerical response $\cdot$ Prey concentration $\cdot$ Production $\cdot Q_{10}$

\section{INTRODUCTION}

Prey concentration and temperature are significant environmental factors that determine the population dynamics and productivity of many aquatic ectotherms. There is a strong body of literature indicating that prey concentration elicits a rectangular hyperbolic response on parameters such as growth rate, ingestion rate and organism size (e.g. Davidson 1996, Weisse et al. 2002, Gentleman et al. 2003). There is an equally large body of literature indicating that many rate processes increase (e.g. Cossins \& Bowler 1987, Mon- tagnes et al. 2003) and organism size decreases (Atkinson et al. 2003) with increasing temperature. However, numeric food web models often treat these 2 variables (temperature, prey concentration) independently, typically imposing one response on the other (see Carlotti et al. 2000).

For instance, a typical scenario in a population model is for growth and grazing rates to be dependent on ambient prey concentration, derived from data collected at a single temperature; then, if temperature were to change in the model, a correction for preydependent rates would be imposed, based on a $Q_{10}$ 
response (e.g. $Q_{10}=2.5$; Caron et al. 1990). The reason for this methodology is simple: few studies simultaneously examine the effect of both temperature and prey concentration. The concern we raise here is that there may be unaccounted for interaction between temperature and prey concentrations that will alter the outcome of such food web models. Collecting data on prey-dependent responses at many temperatures is arduous work. However, we suggest that predictive responses obtained by fitting equations to data sets that vary both temperature and prey concentration will substantially alter the outcome of food web models.

There are already indications that temperature and prey levels should not be treated independently. Food levels that support growth at low temperatures may be inadequate at high temperatures (Weisse et al. 2002 and references within). Thus, interaction between increased temperature and food resources may produce a counterintuitive decrease in productivity (e.g. Lampert 1977). Furthermore, significant temperature-prey interactions occur for a variety of plankters, including copepods, Daphnia spp., rotifers, and ciliates (Orcutt \& Porter 1984, Thébault 1985, Achenbach \& Lampert 1997, Stelzer 1998, Giebelhausen \& Lampert 2001, Weisse et al. 2002). Despite the wealth of information on the impact of temperature and prey concentration on size, and on growth and ingestion rates, the combined effect of these factors has rarely been studied in detail for either metazoans or protozoans. Partially, this lack of data is due to the difficulties of working with organisms with long generation times. Protists, on the other hand, with generation times on the order of hours, are ideal tools to assess the interactive effects of temperature and prey concentration (e.g. Weisse et al. 2002). It is also well recognised that protozoans are important components of many aquatic ecosystems, ranging from the open ocean to sewage systems (Fenchel 1987), all of which can be impacted by both changing prey levels and temperature. Thus, there is a specific need for such studies on protozoans.

The small marine flagellate Oxyrrhis marina Dujardin was chosen as a model to examine the combined effect of food concentration and temperature on specific growth rate, ingestion rate, cell size, and production. This protist is likely ubiquitous (Lowe et al. 2005), and has been used as a model to assess responses to prey type and concentration (Flynn \& Davidson 1993), nutrient regeneration (Davidson et al. 1995), and salinity (Droop 1959, Buskey et al. 1998). In addition, $O$. marina has been used to model bi- and tritrophic grazing interactions (Wolfe \& Steinke 1996), dimethyl sulphide production and grazing selectivity (Wolfe et al. 1997, Wolfe 2000), and the potential control of red-tide organisms (Jeong et al. 2003, Johnson et al. 2003). Thus, further information on this species may not only suggest general relationships but will also build our database on this model organism.

Our aim was first to assess the effects of temperature and food concentration on parameters associated with modelling food webs (e.g. growth rate, ingestion rate, cell size), including the extent of temperature-food concentration interactions. We then briefly used equations that included the combined response to temperature and prey concentration, to illustrate that such equations substantially alter the outputs of resourceconsumer population models compared to those that employ independent $Q_{10}$ functions.

\section{MATERIALS AND METHODS}

Temperature effects on growth and ingestion of Oxyrrhis marina. This study was developed in 4 integrated parts: (1) to visually characterise the interactive effect of temperature and prey concentration on specific growth rate, cell volume, specific production, ingestion, and yield, we examined the effect of prey concentration at several discrete temperatures; (2) to statistically assess the interactions at sub-saturating vs. saturating prey concentrations, we examined the effect of temperature on specific growth rate, cell volume, and production at 3 discrete prey levels established using data from the first set of experiments: zero $\left(0 \mathrm{ml}^{-1}\right)$, sub-saturating $\left(5\right.$ to $\left.70 \times 10^{2} \mathrm{ml}^{-1}\right)$, and saturating $\left(1.8\right.$ to $\left.2.5 \times 10^{5} \mathrm{ml}^{-1}\right)$; (3) to provide predictive equations that describe the combined effects of temperature and food concentration on growth, ingestion, and cell volume, we fitted equations to response-data from all temperature and prey concentration combinations from the 2 experiments mentioned above; finally (4) to illustrate the impact of using these predictive equations compared with applying a $Q_{10}$-response to account for temperature effects, we developed a simple population model and compared its outputs. As the population model provided a synthesis of the study, we have reserved its description and evaluation for the 'Discussion'. Methodological details of the other approaches follow.

Culture methods and experimental design of incubations. Oxyrrhis marina was isolated from a rock pool $\sim 5 \mathrm{~m}$ above mean low tide, $\left(\sim 12^{\circ} \mathrm{C}\right.$, $\left.34 \mathrm{ppt}\right)$ in October 1998 on the Isle of Man $\left(54^{\circ} 4.06^{\prime} \mathrm{N}, 04^{\circ} 44.25^{\prime} \mathrm{W}\right)$; it was maintained on the $\sim 5 \mu \mathrm{m}$ cryptophyte Isochrysis galbana (Culture Collection of the Marine Biological Laboratory, Helsingør, Denmark). Both O. marina and I. galbana were maintained at $15 \pm 0.5^{\circ} \mathrm{C}$ in $\mathrm{f} / 2$ medium (Guillard 1972) and harvested in exponential phase for experiments. I. galbana was exposed to $150 \mu \mathrm{mol}$ photons $\mathrm{m}^{-2} \mathrm{~s}^{-1}$ on a 14:10 h light:dark cycle. 
Growth and ingestion rates and cell size were determined for Oxyrrhis marina between 8 and $30^{\circ} \mathrm{C}$ at 20 to 30 Isochrysis galbana (prey) concentrations ranging from $10^{2}$ to $2.5 \times 10^{5} \mathrm{ml}^{-1}$ (concentrations shown in Figs. 1 to 5). For prey-response experiments at discrete temperatures there was no replication (e.g. see Fig. 1), while for temperature-response experiments at the 3 discrete prey levels each temperature-prey treatment was replicated ( $n=3$; e.g. see Fig. 2).

The experiments were conducted in temperaturecontrolled water-baths, in the dark, in $250 \mathrm{ml}$ polycarbonate bottles that were continuously mixed by gentle rotation. Cultures were acclimated to the experimental conditions for at least 1 generation, after which initial counts were made, and were then incubated for $24 \mathrm{~h}$, after which final counts were made. Densities of liveprey and Lugol-fixed ( $2 \%$ final volume) Oxyrrhis marina were measured: live-prey densities were determined using a Model II Coulter Counter, and fixed $O$. marina densities were determined using a Sedgewick-Rafter chamber. O. marina cell volume was estimated from $\geq 50$ cells (obtained at the end of each $24 \mathrm{~h}$ incubation), using length and width measurements and assuming a prolate spheroid shape. All $O$. marina size measurements were made on acid Lugolfixed material (final concentration $2 \%$ ) and volume was calculated taking into account fixation-induced shrinkage (Montagnes et al. 1994).

Parameters measured in incubations. Specific growth rate $\left(\mu, \mathrm{d}^{-1}\right)$ of Oxyrrhis marina was calculated assuming exponential growth over 24 h: i.e. $\mu=\ln \left(N_{t}-\right.$ $N_{0}$ ) $/ t$, where $N_{0}$ and $N_{t}$ are initial and final $O$. marina numbers, respectively, and $t(\mathrm{~d})$ is the experiment duration. The geometric mean prey concentration was determined in each bottle over the $24 \mathrm{~h}$ incubation; although prey numbers decreased during incubation, densities remained sufficiently constant to allow the assumption that, relative to other prey treatments, changes would not alter the assumption of constant exponential growth over $24 \mathrm{~h}$. Ingestion rate $(I)$ by $O$. marina was calculated from prey depletion (using initial and final prey counts) compared to controls, following equations outlined by Heinbokel (1978). O. marina carbon content was determined from volumes (0.099 pg $\mu^{-3}$; Menden-Deuer \& Lessard 2000). Specific production $(S p)$ of $O$. marina was calculated after Montagnes \& Weisse (2000), modified by converting volume to biomass: $S p=\mu(v \cdot \mathrm{OC})$, where $\mu=$ specific growth rate $\left(\mathrm{d}^{-1}\right) ; v=O$. marina cell volume $\left(\mu \mathrm{m}^{3}\right)$; and $\mathrm{OC}=O$. marina carbon $\left(\mathrm{pg} \mathrm{C} \mu \mathrm{m}^{-3}\right)$. Yield (=gross growth efficiency, Fenchel 1982) was calculated as: yield $=S p /(I \cdot \mathrm{pC})$, where $I$ (ingestion) $=$ prey $O$. marina ${ }^{-1} \mathrm{~d}^{-1}$ and $\mathrm{pC}=\mathrm{pg}$ carbon Isochrysis galbana ${ }^{-1}$, calculated from the temperature-volume and carbonvolume relationships of Montagnes \& Franklin (2001).
Response models. To characterise the interactive effect of temperature and prey concentration on specific growth rate, ingestion, cell volume, and specific production, we fitted established response models (e.g. Montagnes \& Lessard 1999) to data from experiments conducted at discrete temperatures. Curves were generated by an iterative fitting method, using the Marquardt-Levenberg least squares algorithm (Sigmaplot Version 5, 1999, SPSS); this algorithm is appropriate for describing such biological data sets (Berges et al. 1994). Numerical responses, with non-zero intercepts, were established by fitting Eq. (1) to growth rate data. Functional responses were established by fitting Eq. (2) to ingestion rate data. The response of cell volume to prey concentration was established by fitting Eq. (3) to cell volume data. The response of specific production to prey concentration was established by fitting Eq. (4) to specific production data:

$$
\begin{gathered}
\mu=\frac{\mu_{\max } \times\left(p-p^{\prime}\right)}{k_{1}+\left(p-p^{\prime}\right)} \\
I=\frac{I_{\max } \times p}{k_{2}+p} \\
V=\frac{V_{\max } \times p}{k_{3}+p}+C \\
S p=\frac{S p_{\max } \times\left(p-p^{\prime}\right)}{k_{4}+\left(p-p^{\prime}\right)}
\end{gathered}
$$

where $\mu=$ growth rate $\left(\mathrm{d}^{-1}\right) ; \mu_{\max }=$ maximum growth rate $\left(\mathrm{d}^{-1}\right) ; p=$ the geometric mean prey concentration $\left(\mathrm{ml}^{-1}\right) ; p^{\prime}=$ threshold concentration (prey concentration at which $\mu=0$ or $S p=0$ ); $I=$ ingestion rate (prey Oxyrrhis marina $\left.{ }^{-1} \mathrm{~h}^{-1}\right) ; I_{\max }=$ maximum ingestion rate (prey O. marina $\left.{ }^{-1} \mathrm{~h}^{-1}\right) ; v=$ cell volume $\left(\mu \mathrm{m}^{3}\right) ; V_{\max }=$

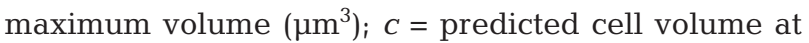
zero prey $\left(\mu \mathrm{m}^{3}\right) ; S p=$ specific production $\left(\mathrm{pg} \mathrm{C} \mathrm{d} \mathrm{d}^{-1}\right)$; $S p_{\max }=$ maximum specific production $\left(\mathrm{pg} \mathrm{C} \mathrm{d}{ }^{-1}\right) ; k_{1}, k_{2}$, $k_{3}, k_{4}=$ are constants $\left(\mathrm{ml}^{-1}\right)$.

Statistical tests for interaction. To assess for interactive effects in the temperature-response experiments conducted at the 3 discrete prey levels (zero, sub-saturating, saturating), analysis of covariance was applied to the specific growth rate and cell volume data. When linear trends with temperature were not apparent, analysis of variance was applied to test for interactive effects.

Cell volume data were further investigated. The relationship between temperature and cell volume in protists has been studied by calculating the slope of the volume-temperature relationship divided by cell volume at a reference temperature $\left(15^{\circ} \mathrm{C}\right)$; this parameter, presented as a percent change in volume with temperature $\left(\%{ }^{\circ} \mathrm{C}^{-1}\right)$, is referred to as the relative thermal sensitivity of cell volume (Atkinson et al. 2003). 
Following Atkinson et al. (2003), the relative thermal sensitivity of cell volume was calculated at saturating and sub-saturating prey concentrations, and analysis of covariance was applied to test for interactive effects.

Predictive models. Curves were iteratively fit to response-data from all temperatures and prey concentration combinations using the Marquardt-Levenberg least squares algorithm, and parameters were determined. Initially a number of alternative predictive equations were fitted to the data (see Kimmance 2001 for details), and the most appropriate were selected based on their biological suitability (related to Eqs. 1 to 4 above) and best fit to the data; i.e. where regressions were significant, $\mathrm{p}<0.05$, and had the highest adjusted $\mathrm{R}^{2}$ value.

\section{RESULTS}

\section{Temperature effects on growth and ingestion parameters}

Specific growth rate of Oxyrrhis marina generally followed a rectangular hyperbolic response with a positive prey-intercept (Fig. 1, Eq. 1). As temperature increased, both the maximum growth rate and threshold food concentration (i.e. the prey concentration where $\mu=0$ ) increased (Figs. 1 \& 2d), suggesting an interactive effect of temperature and prey concentration on specific growth rate. Further investigation supported this, as the response of the specific growth rate of $O$. marina to temperature differed between the 3 food levels (Fig. 2a). At saturating prey concentrations, mean specific growth rate increased with increasing temperature until $25^{\circ} \mathrm{C}$; at $28^{\circ} \mathrm{C}$ growth decreased. At sub-saturating prey levels, mean specific growth rate also increased with increasing temperature, but the maximum occurred at $18^{\circ} \mathrm{C}$. At zero prey concentration, specific growth rate decreased with increasing temperature, becoming negative at $25^{\circ} \mathrm{C}$. The apparent (but not significant) positive growth when no food was present (Fig. 2a) may have been due to cells dividing without increasing in size. Analysis of covariance indicated an interaction: for saturating prey (between 8 and $20^{\circ} \mathrm{C}$ ) and subsaturating prey (between 8 and $18^{\circ} \mathrm{C}$ ), specific growth rate increased linearly with increasing temperature (Fig. 2a), but over these ranges the slopes differed $(p<0.05)$.

Oxyrrhis marina cell volume generally increased with increasing prey concentration and decreased with increasing temperature (Fig. 1). The relationship between $O$. marina cell volume and prey concentration (Eq. 3) changed as a function of experimental temperature (Fig. 1), suggesting an interactive effect of temperature and prey level on predator volume. Further investigation supported this, as the relationship between $O$. marina volume and temperature differed between the 3 prey concentrations (Fig. 2b): analysis of covariance indicated that the slope of cell volume vs. temperature was significantly lower at subsaturating prey concentrations than at growth-saturating levels $(p<0.05)$. Specifically, at zero prey concentration, the relative thermal sensitivity of $O$. marina cell volume was $2 \%{ }^{\circ} \mathrm{C}^{-1}$; at sub-saturating prey concentrations it was $1 \%{ }^{\circ} \mathrm{C}^{-1}$, and at saturating prey concentrations it was $6 \%{ }^{\circ} \mathrm{C}^{-1}$. 

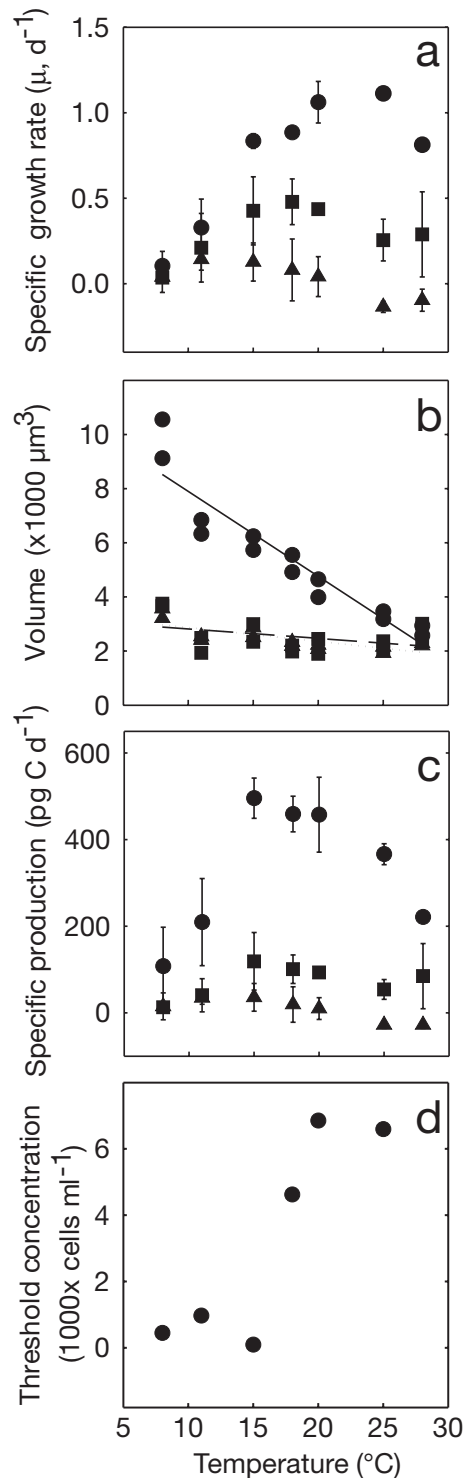

Fig. 2. Oxyrrhis marina. Response (mean $\pm \mathrm{SE}$ ) of specific growth rate, cell volume, specific production (product of specific growth rate and cell carbon), and threshold concentration (where $\mu=0$ ) to temperature at 3 prey (Isochrysis gal-

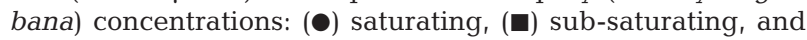

(ム) zero prey; see 'Materials and methods' for details

Specific production $(S p)$ of Oxyrrhis marina generally increased with both increasing temperature and increasing prey concentration, following a rectangular hyperbolic response (Eq. 4, Fig. 1). As temperature increased, $S p_{\max }$ increased, and the shape of the hyperbolic function differed between temperatures, suggesting an interaction (Fig. 1). When specific production was examined at the 3 discrete prey concentrations (Fig. 2c), there was further evidence of an interactive effect. Specific growth rate increased and cell volume decreased with increasing temperature (see above), but the product of these $(S p)$ showed a dif- ferent response. Specific production was virtually zero below 15 to $18^{\circ} \mathrm{C}$ in the no-prey treatment. Unlike the maximum specific growth rate, which occurred at different temperatures depending on prey level, specific production peaked at $\sim 15^{\circ} \mathrm{C}$ at both saturating and sub-saturating prey levels. However, production was much lower at sub-saturating concentrations (Fig. 2c).

The ingestion rate of Oxyrrhis marina increased with increasing food concentration and temperature, following a rectangular hyperbolic function with an $x$-intercept of zero (Eq. 2, Fig. 3). At lower temperatures ingestion rate tended to increase more linearly with increasing food concentration (Fig. 3), suggesting an interactive effect of food level and temperature on ingestion. The ingestion rates at sub-saturating levels were not ob-
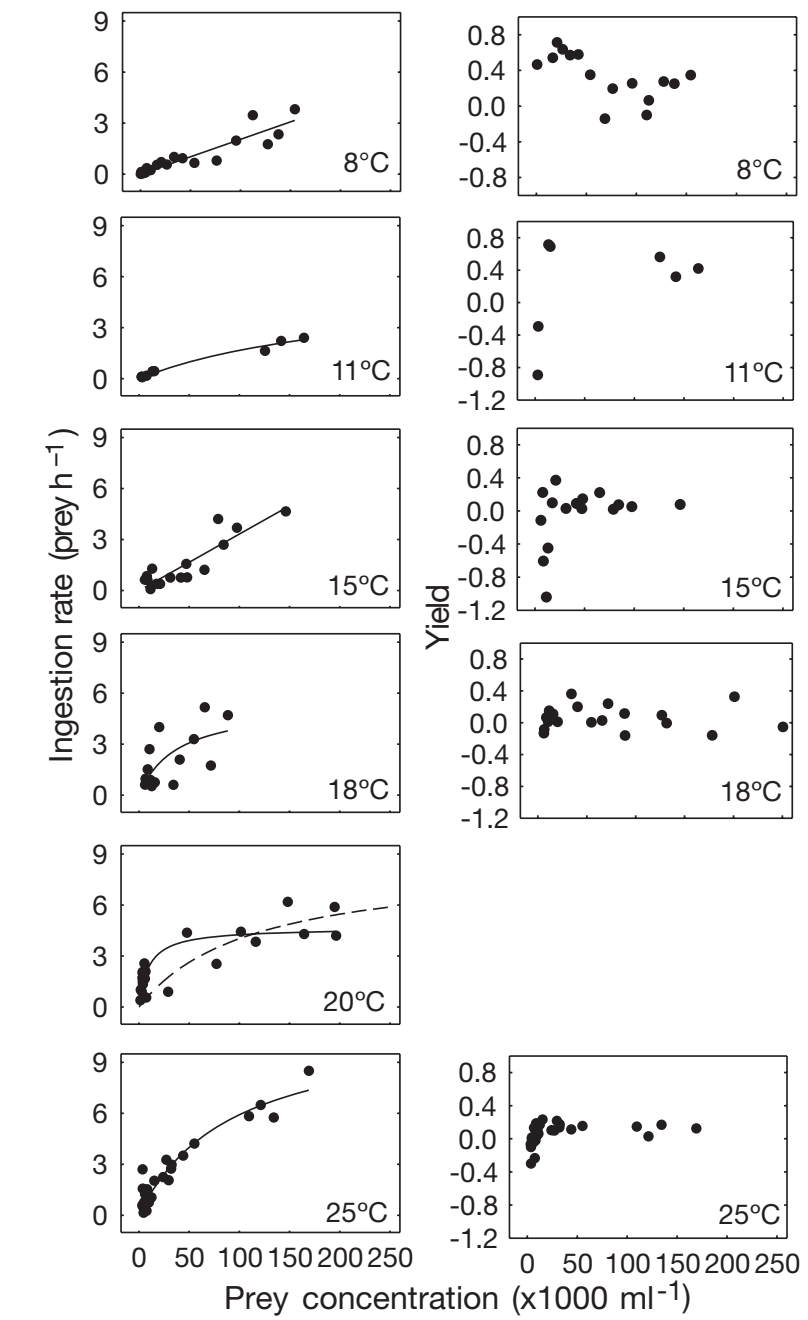

Fig. 3. Oxyrrhis marina. Response of specific ingestion rate and yield (=gross growth efficiency) to prey concentration (Isochrysis galbana) at temperatures ranging from 8 to $25^{\circ} \mathrm{C}$. Continuous lines are the best fit to the data. The dashed line in $20^{\circ} \mathrm{C}$ ingestion rate panel was used to assess models (see 'Discussion: Application of interaction between temperature and prey concentration') 
tained, therefore the interaction was not statistically tested. Ingestion rate at saturating prey levels for growth (see Fig. 1), however, increased with increasing temperature between 8 and $20^{\circ} \mathrm{C}$ (Fig. $4 \mathrm{a}$ ), but above $25^{\circ} \mathrm{C}$, there was a decline in ingestion rate, and at $28^{\circ} \mathrm{C}$ it was reduced to nearly the same level as at $8^{\circ} \mathrm{C}$ (Fig. $4 \mathrm{a}$ ).

Oxyrrhis marina yield (gross growth efficiency) depended on prey concentration (Fig. 3). A maximum yield of 0.6 to 0.7 occurred between 8 and $11^{\circ} \mathrm{C}$, at $\sim 2 \times$ $10^{4}$ prey $\mathrm{ml}^{-1}$. At $8^{\circ} \mathrm{C}$, there appeared to be a decrease in yield with increased prey concentration (Fig. 3). At $11,15,18$, and $25^{\circ} \mathrm{C}$, yield initially increased with increasing prey concentration and then reached an asymptote (Fig. 3). O. marina yield at growth-saturating prey levels ranged from 0.04 to 0.43 (Fig. 4b), and exhibited no clear relationship with temperature when data from both sets of experiments were combined. Furthermore, analysis of variance indicated that there was no effect of temperature on yield when only the saturating prey concentrations, from the second set of experiments, was considered $(p>0.05)$.

\section{Predictive models}

The response of Oxyrrhis marina specific growth rate to the combined effects of temperature and prey concentration was best described by Eq. (5) ( $p<0.05$, adjusted $R^{2}=0.53$, Fig. $5 a$ ), where $\mu=$ specific growth rate $\left(\mathrm{d}^{-1}\right), p=$ prey concentration $\left(\mathrm{ml}^{-1}\right)$, and $t=$ temper-

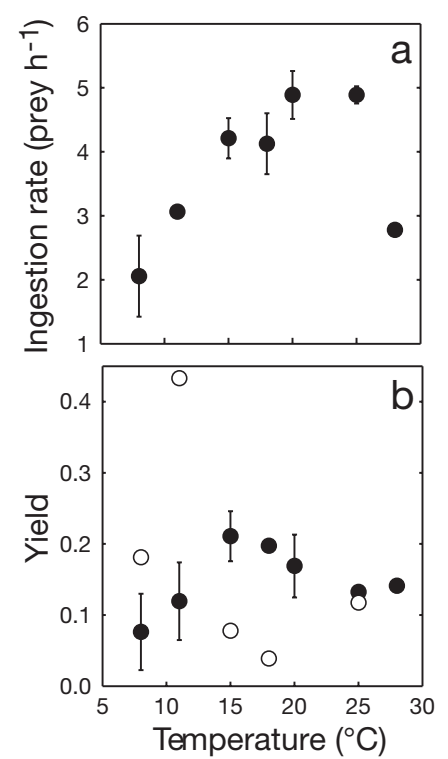

Fig. 4. Oxyrrhis marina. Response (mean $\pm \mathrm{SD}$ ) of (a) ingestion rate and (b) yield to temperature at saturating prey (Isochrysis galbana) concentration. (•) Data from a set of experiments run only at saturating prey levels (see 'Materials and methods' for details); (O) from asymptotic values obtained from yield data in Fig. 3 ature $\left({ }^{\circ} \mathrm{C}\right)$. The response of the ingestion rate to the combined effects of temperature and prey concentration was best described by Eq. (6) ( $p<0.05$, adjusted $\mathrm{R}^{2}$ $=0.59$, Fig. $5 \mathrm{~b})$, where $I=$ ingestion rate $\left(\right.$ prey $\left.\mathrm{h}^{-1}\right)$. The response of cell volume to the combined effects of temperature and prey concentration was best described by Eq. (7) $\left(\mathrm{p}<0.05\right.$, adjusted $\mathrm{R}^{2}=0.86$, Fig. $\left.5 \mathrm{c}\right)$, where $v=$ O. marina cell volume $\left(\mu^{3}\right)$ :

$$
\begin{gathered}
\mu=\frac{0.94 \times(p-6393)}{14160+(p-6393)} \times 0.05 t \\
I=\frac{23.74 \times p}{112010+p} \times 0.28(t-7.99)^{0.10} \\
V=\left(\frac{54000 \times p}{360000+p}+16412\right) \times\left(1.44 \times t^{-0.86}\right)
\end{gathered}
$$
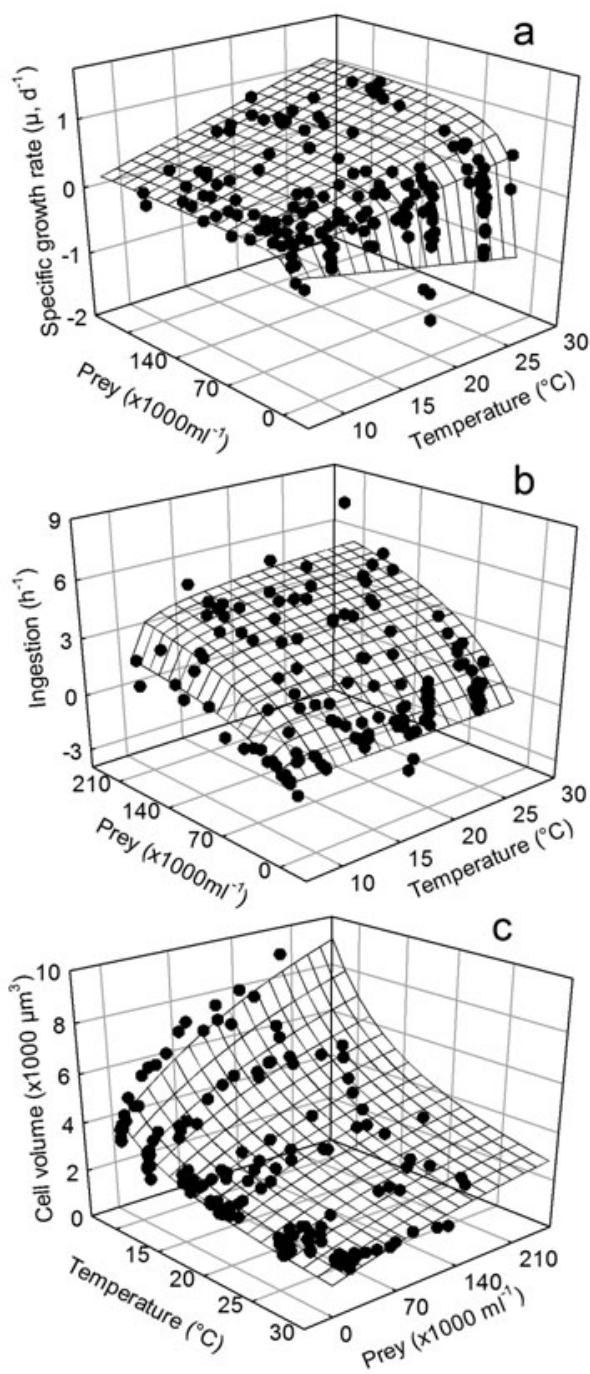

Fig. 5. Oxyrrhis marina. Response of specific growth rate, ingestion rate, and cell volume to the combined effects of temperature and prey (Isochrysis galbana) concentration; data points obtained from all experiments; fits to data (mesh) in (a), (b) and (c) follow Eqs. (5), (6) \& (7), respectively 


\section{DISCUSSION}

\section{Prey concentration}

It is well established that protists typically follow Holling Type II, rectangular hyperbolic, functional and numerical responses, and Oxyrrhis marina is no exception. It is possible that some protists may elicit a sigmoidal, Type III, functional or numerical response, but in most studies data are rarely sufficiently precise to assess this, and we were not able to do so here. Similarly, we were not able to detect a threshold level for ingestion rate (i.e. the functional response was best modelled by Eq. 2). In contrast, we were able to reveal that $O$. marina exhibits a threshold prey level, where growth is zero. Such a threshold level for heterotrophic dinoflagellates (to which O. marina is related: Lowe et al. 2005) is well supported in the literature, with values typically ranging from 10 to $10^{3} \mu \mathrm{g} \mathrm{C} \mathrm{l}^{-1}$ (Jacobson 1987, Bjørnsen \& Kuparinen 1991, Strom 1991, Hansen 1992, Strom \& Buskey 1993, Buskey et al. 1994, Jeong \& Latz 1994, Jakobsen \& Hansen 1997). Threshold levels can be used to assess whether conditions are adequate to allow a predator to survive; our data suggest that $O$. marina can survive at relatively low prey levels (1 to $80 \mu \mathrm{g} \mathrm{C} \mathrm{l}^{-1}$ ). Furthermore, establishing threshold levels (and mortality rates below them) may be critical for parameterising foodweb models, as they allow predators to die from starvation rather than being consumed by predators (Montagnes 1996).

There is also a tendency for some protists to be deleteriously affected at high prey concentrations (e.g. Montagnes \& Lessard 1999), but this did not occur for Oxyrrhis marina. Its growth rate reached an asymptote and production and ingestion rate tended to increase, even to $>10^{5}$ prey $\mathrm{ml}^{-1}$, suggesting that this species can occur and thrive at relatively high prey levels. Cell volume may also increase with increasing prey concentration (e.g. Montagnes \& Lessard 1999), and this occurred for $O$. marina, becoming asymptotic at high prey levels. Thus, in general it appears that $O$. marina is able to survive at low prey levels and thrive at high prey levels. In fact, our specific production data indicate that $O$. marina can be extremely productive at temperatures of 18 to $25^{\circ} \mathrm{C}$ and prey concentrations $>10^{5} \mathrm{ml}^{-1}$.

Yield (gross growth efficiency) also varied as a function of prey concentration. Basic maintenance requires food, and thus a threshold prey concentration for growth exists. Consequently, at this threshold prey concentration, yield (by definition) is zero, and it will increase above this level to a maximum. This is what occurred for Oxyrrhis marina. More interestingly, yield tends to decrease at higher prey levels, suggesting a reduction in efficiency at very high levels, as occasionally seen in other planktonic taxa (Valiela 1995).

Protists are often thought to be efficient feeders, with high yields, and studies typically use protozoan yield $>40 \%$ to calculate ingestion or growth rates from growth and ingestion rates, respectively (e.g. Caron \& Goldman 1990 and references therein, Bjørnsen \& Kuparinen 1991, Archer et al. 1996). However, Straile (1997) found that a protist yield of $\sim 20-30 \%$ may be more appropriate, decreasing to $\sim 10-20 \%$ when food is abundant, which is consistent with at least some of our findings (Fig. 3). Our findings support the application of variable yields, an observation that should be noted by modellers.

\section{Temperature}

Both protistan growth rate and cell volume can be modelled as linear functions of temperature (Atkinson et al. 2003, Montagnes et al. 2003), and the data from this study support this, at least over limited ranges. Our data also suggest that ingestion increases linearly with increasing temperature between 8 and $15^{\circ} \mathrm{C}$ (Fig. 4), but as saturating prey levels were not reached for grazing rate at all temperatures (cf. Figs. 1 \& 3), further data collection is still required to assess this trend.

The data (Fig. 2d) suggest that the threshold prey concentration, where growth is zero, increases with increasing temperature. This agrees with our previous work (Weisse et al. 2002) on the freshwater ciliate Urotricha farcta, where a step-wise shift from a low threshold at low temperatures to a high threshold at high temperatures also occurred. Possibly this shift reflects a change in physiological state, whereby catabolic processes at higher temperatures dominate, requiring a substantially higher food intake to achieve growth (Atkinson \& Sibly 1996).

Finally, yield appeared to show no clear trend with temperature in this study. Yield should change if there is an imbalance in anabolic and catabolic processes with a change in temperature (Angilletta \& Dunham 2003): data from single- and multi-species studies suggest that protistan yield may increase (Laybourn \& Stewart 1975, Rogerson 1981, Sherr et al. 1983, Straile 1997) or decrease (Rassoulzadegan 1982, Verity 1985, Caron et al. 1990, Straile 1997) with increasing temperature. This diversity of responses to temperature is also seen in various Metazoans (Straile 1997, Angilletta \& Dunham 2003). Thus, no clear, single, temperatureyield relationship is evident, which combined with the general adaptation of most organisms to ambient temperature should mean that yield will show no strong temperature-dependence in the field (Straile 1997). 


\section{Interaction between temperature and prey concentration}

There is clearly an interactive effect between temperature and prey concentration on a variety of the parameters studied. The threshold level for growth seemed to increase stepwise, and specific growth rate and cell volume responded differently under saturating and sub-saturating prey concentrations, depending on temperature (Fig. 2). Furthermore, the shape of the functional, numerical, volume, and production responses differed as a function of temperature (Figs. 1 to 3$)$.
Understanding the physiological basis of temperature-food interactions was not specifically the purpose of this work. However, our data do reveal some potential trends. For instance, the increased effect of food concentration on specific growth rate with increasing temperature (Fig. 2a), which was consistent with the higher threshold prey concentration at increased temperatures (Fig. 2d), is probably caused by higher rates of catabolism necessary for survival (e.g. maintaining ionic gradients, protein turnover: Clarke \& Fraser 2004). Furthermore, the range of relative thermal sensitivities of cell volume, from $6 \%$ at saturating prey concentrations to $2 \%$ at sub-saturating concentrations,
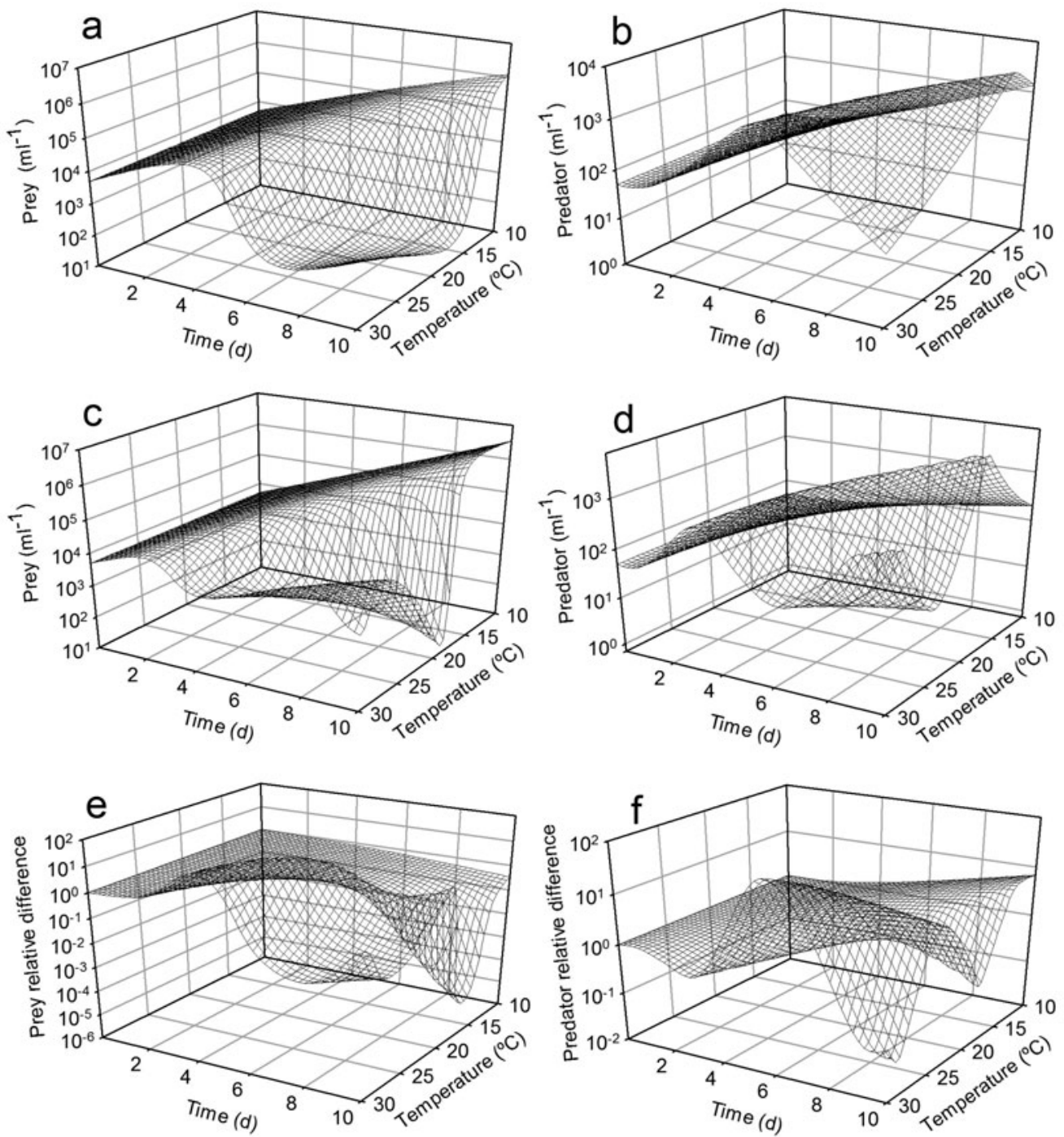

Fig. 6. Oxyrrhis marina and Isochrysis galbana. Modelled population dynamics of (a,c,e) prey I. galbana and (b,d,f) predator $O$. marina over a $10 \mathrm{~d}$ simulation. For (a) and (b), specific growth rate and ingestion were determined directly from Eqs. (5) \& (6), respectively; thus, in this case the combined effects of ambient temperature and prey concentration were included. For (c) and (d), specific growth rate and ingestion rate were determined only at $20^{\circ} \mathrm{C}$ from Eqs. (5) \& (6), respectively (dashed line at $20^{\circ} \mathrm{C}$ in Figs. 1 \& 3). Subsequently, to determine the response at other temperatures, a $Q_{10}$ of 2.5 was applied to the values obtained at $20^{\circ} \mathrm{C}$. (e,f) Relative difference between the 2 scenarios, i.e. the ratio of prey (a:c) and predators (b:d). Predator and prey concentrations are on log-scales 
spans the mean value of $2.5 \%{ }^{\circ} \mathrm{C}^{-1}$ observed by Atkinson et al. (2003) for protists, but this significant decrease in slope is due to prey limitation at low temperature, not high temperature as occurred for specific growth rate, suggesting a different mechanism underlying temperature-prey dependency on cell size. Investigating the mechanisms underlying such responses is a goal of our ongoing research, to provide insight into the widespread inverse relationship between temperature and body size in ectotherms (Atkinson \& Sibly 1997) and into the scaling of biological rates in general (Brown et al. 2004), as well as helping to provide predictive relationships for ecosystem modelling.

Recognising that interaction occurred, however, we set forth to model these responses, for predictive purposes, by fitting a variety of phenomenological models to the entire data set accumulated from the 2 sets of experiments. The best fits (Eqs. 5 to 7 ) take into account the effects of temperature-food combinations without adding unjustified complexity of additional interaction terms. Furthermore, they provide both prey concentration- and temperature-dependent components, allowing us to easily manipulate the equations based on their parts. Thus, we have provided predictive equations for future modelling, and a simple example of their implications follows.

\section{Model application of interaction between temperature and prey concentration}

As indicated in the 'Introduction', there is a tendency in numeric ecosystem modelling to treat food concentration and temperature independently (Carlotti et al. 2000). Here we use our detailed data on 1 species to illustrate that this may be inappropriate, as temperature and food affect growth and ingestion parameters differently when examined in combination; this may then alter the outcome of food web models. To demonstrate this, Oxyrrhis marina growth and grazing responses (Eqs. 5 \& 6) were applied to a simple model of predator-prey dynamics. In this illustrative example, volume changes (Eq. 7) were not included. The inclusion of volume would alter the predictions related to food web productivity; clearly all 3 equations would need to be incorporated into ecosystem models that consider carbon flux.

Using STELLA 8 (High Performance Systems), a predator-prey model was simulated, whereby the flagellate Isochrysis galbana grows exponentially and is preyed upon by Oxyrrhis marina, with no higher level predators consuming the flagellate; thus, $O$. marina mortality is regulated strictly by starvation below threshold levels (i.e. $\mathrm{d} P / \mathrm{d} t=\mu_{\mathrm{p}} P-I N$ and $\mathrm{d} N / \mathrm{d} t=\mu_{\mathrm{N}} N$, where $P=I$. galbana abundance; $\mu_{\mathrm{p}}=$ temperature-dependent specific growth rate of $I$. galbana; $I$ = temperature- and prey-dependent grazing by $O$. marina; $N=O$. marina abundance; $\mu_{N}=$ temperature- and prey-dependent specific growth rate of $O$. marina). The simulation lasted $10 \mathrm{~d}$, a period sufficiently long, at $20^{\circ} \mathrm{C}$, to express 1 predator-prey cycle, given initial conditions of $5 \times 10^{3}$ prey and 50 predators $\mathrm{ml}^{-1}$ (the starting condition of all simulations).

In the first application of the model, Oxyrrhis marina specific growth rate $\left(\mu_{\mathrm{N}}\right)$ and ingestion $(I)$ were determined directly from Eqs. (5) \& (6), respectively; thus in this case the combined effects of ambient temperature and prey concentration were included. In the second application of the model, O. marina specific growth rate and ingestion rate were determined only from the predicted response at $20^{\circ} \mathrm{C}$, from Eqs. (5) \& (6), respectively (Figs. $1 \& 3$, dashed lines at $20^{\circ} \mathrm{C}$ ). Then a $Q_{10}$ of 2.5 (see Caron et al. 1990) was applied to the growth and grazing rates at given prey concentrations at $20^{\circ} \mathrm{C}$ to determine the response at other temperatures. This latter scenario represents the typical way in which many ecosystem models rely on the limited data that are available. In both cases, Isochrysis galbana specific growth rate $\left(\mu_{\mathrm{p}}\right)$ was determined as a linear response to temperature $\left(\mu_{\mathrm{p}}=\right.$ temperature $\left.\times 0.01+0.576\right)$, as this best represents the growth rate of $I$. galbana (Montagnes \& Franklin 2001).

The model output (Fig. 6) illustrates the difference between applying a full temperature-prey-derived response and simply modifying a single response using a $Q_{10}$ function. At $20^{\circ} \mathrm{C}$ the 2 responses are identical, as they were derived from identical equations. However, above and below this temperature there is deviation in the responses (Fig. 6e,f). This simulation is not an indication of natural conditions, as the prey have not been bottom-up limited (e.g. nutrients), nor has the predator been top-down limited (e.g. copepod grazing). Nor is the model exhaustive. Still, the output does illustrate our point that inclusion of equations that incorporate the effects of temperature-prey concentration combinations will substantially influence the outcome of food web models. We recommend that the present application of correction factors such as $Q_{10}$ be reconsidered in the future and that continued effort be made to evaluate the effect of interaction between these 2 key variables on plankton dynamics.

Acknowledgements. This study formed part of the $\mathrm{PhD}$ studies conducted by S.A.K. at Port Erin Marine Laboratory, University of Liverpool. The work was supported by a Natural Environment Research Council (NERC) studentship. Manuscript preparation was supported by a NERC grant (NER/A/ S/2001/00574). 


\section{LITERATURE CITED}

Achenbach L, Lampert W (1997) Effects of elevated temperatures on threshold food concentrations and possible competitive abilities of differently sized cladoceran species. Oikos 79:469-476

Angilletta MJ Jr, Dunham AE (2003) The temperature-size rule in ectotherms: simple evolutionary explanations may not be general. Am Nat 162:332-342

Archer SD, Leakey RJG, Burkill PH, Sleigh MA (1996) Microbial dynamics in coastal waters of East Antarctica: herbivory by heterotrophic dinoflagellates. Mar Ecol Prog Ser 139:239-255

Atkinson D, Sibly RM (1996) On the solutions to a major lifehistory puzzle. Oikos 77:359-365

Atkinson D, Sibly RM (1997) Why are organisms usually bigger in colder environments? Making sense of a life history puzzle. Trends Ecol Evol 12:235-239

Atkinson D, Ciotti BJ, Montagnes DJS (2003) Protists decrease in size linearly with temperature: ca. $2.5^{\circ} \mathrm{C}^{-1}$. Proc R Soc Lond B 270:2605-2611

Berges JA, Montagnes DJS, Hurd CL, Harrison PJ (1994) Fitting ecological and physiological data to rectangular hyperbolae: a comparison of methods using Monte Carlo simulations. Mar Ecol Prog Ser 114:175-183

Bjørnsen PK, Kuparinen J (1991) Growth and herbivory by heterotrophic dinoflagellates in the Southern Ocean, studied by microcosm experiments. Mar Biol 109:397-405

Brown JH, Gillooly JF, Allen AP, Savage VM, West GB (2004) Towards a metabolic theory of ecology. Ecology 85: 1771-1789

Buskey EJ, Coulter CJ, Brown SL (1994) Feeding, growth, and bioluminescence of the heterotrophic dinoflagellate Protoperidinium-huberi on varying algal diets. Mar Biol 121: 373-380

Buskey EJ, Wysor B, Hyatt C (1998) The role of hypersalinity in the persistence of the Texas 'brown tide' in the Laguna Madre. J Plankton Res 20:1553-1565

Carlotti F, Giske J, Werner F (2000) Modeling zooplankton dynamics. In: Harris R, Wiebe P, Lenz J, Skjodal, HR, Huntley M (ed) ICES zooplankton methodology manual. Academic Press, New York, p 571-668

Caron DA, Goldman JC (1990) Protozoan nutrient regeneration. In: Capriulo GM (ed) Ecology of marine protozoa. Oxford University Press, Oxford, p 283-306

Caron DA, Goldman JC, Fenchel T (1990) Protozoan respiration and metabolism. In: Capriulo GM (ed) Ecology of marine protozoa. Oxford University Press, Oxford, p 307-322

Clarke A, Fraser KPP (2004) Why does metabolism scale with temperature? Funct Ecol 18:243-251

Cossins AR, Bowler K (1987) Temperature biology of animals. Chapman \& Hall, London

Davidson K, Cunningham A, Flynn KJ (1995) Predator-prey interactions between Isochrysis galbana and Oxyrrhis marina. 3. Mathematical modelling of predation and nutrient regeneration. J Plankton Res 17:465-492

Davidson K (1996) Accounting for nutrient processing time in mathematical models of phytoplankton growth. Limnol Oceanogr 41:779-783

Droop MR (1959) A note on some physical conditions for cultivating Oxyrrhis marina. J Mar Biol Assoc UK 38:599-604

Fenchel T (1982) Ecology of heterotrophic microflagellates. 2. Bioenergetics and growth. Mar Ecol Prog Ser 8:225-231

Fenchel T (1987) Ecology of Protozoa - the biology of freeliving phagotrophic protists. Springer-Verlag, Berlin

Flynn KJ, Davidson K (1993) Predator-prey interactions between Isochrysis galbana and Oxyrrhis marina. 2.
Release of non-protein amines and faeces during predation of Isochrysis. J Plankton Res 15:893-905

Gentleman WC, Leising A, Frost B, Strom S, Murray J (2003) Functional responses for zooplankton feeding on multiple resources: a review of assumptions and biological dynamics. Deep-Sea Res II 50:2847-2875

Giebelhausen B, Lampert W (2001) Temperature reaction norms of Daphnia magna: the effect of food concentration. Freshw Biol 46:281-289

Guillard RRL (1972) Culture of phytoplankton for feeding marine invertebrates. In: Smith WL, Chanley MW (eds) Culture of marine invertebrate animals. Plenum Press, New York, p 29-60

Hansen PJ (1992) Prey size selection, feeding rates and growth dynamics of heterotrophic dinoflagellates with special emphasis on Gyrodinium spirale. Mar Biol 114: $327-334$

Heinbokel JF (1978) Studies on the functional role of tintinnids in the southern California Bight. 1. Grazing and growth rates in laboratory cultures. Mar Biol 47:177-189

Jacobson DM (1987) The ecology and feeding behaviour of thecate heterotrophic dinoflagellates. PhD thesis, Massachusetts Institute of Technology and Woods Hole Oceanographic Institution, Woods Hole, MA

Jakobsen HH, Hansen PJ (1997) Prey size selection, grazing and growth response of the small heterotrophic dinoflagellate Gymnodinium sp. and the ciliate Balanion comatum - a comparative study. Mar Ecol Prog Ser 158: $75-86$

Jeong HJ, Latz MI (1994) Growth and grazing rates of the heterotrophic dinoflagellates Protoperidinium spp. on red tide dinoflagellates. Mar Ecol Prog Ser 106:173-185

Jeong HJ, Kim JS, Yeong DY, Kim ST and 6 others (2003) Feeding by the heterotrophic dinoflagellate Oxyrrhis marina on the red-tide raphidophyte Heterosigma akashiwo: a potential biological method to control red tides using mass-cultured grazers. J Eukaryot Microbiol 50: $274-282$

Johnson MD, Rome M, Stoecker DK (2003) Microzooplankton grazing on Prorocentrum minimum and Karlodinium micrum in Chesapeake Bay. Limnol Oceanogr 48:238-248

Kimmance SA (2001) The interactive effects of temperature and food concentration on growth responses of aquatic protists, with particular reference to the heterotrophic dinoflagellate Oxyrrhis marina. PhD thesis, University of Liverpool

Lampert W (1977) Studies on the carbon balance of Daphnia pulex de Geer as related to environmental conditions. 3. Production and production efficiency. Arch Hydrobiol (Suppl) 48:336-360

Laybourn JE, Stewart JM (1975) Studies on consumption and growth in the ciliate Colpidium campylum Stokes. J Anim Ecol 44:165-174

Lowe CD, Day, A Kemp SJ, Montagnes DJS (2005) There are high levels of functional and genetic diversity in Oxyrrhis marina. J Eukaroyt Microbiol 52:250-257

Menden-Deuer S, Lessard EJ (2000) Carbon to volume relationships for dinoflagellates, diatoms and other protist plankton. Limnol Oceanogr 45:569-579

Montagnes DJS (1996) Growth responses of planktonic ciliates in the genera Strobilidium and Strombidium. Mar Ecol Prog Ser 130:242-254

Montagnes DJS, Franklin DJ (2001) Effect of temperature on diatom volume, growth rate, and carbon and nitrogen content: reconsidering some paradigms. Limnol Oceanogr 46: $2008-2018$

Montagnes DJS, Lessard EJ (1999) Population dynamics of 
the marine planktonic ciliate Strombidinopsis multiauris: its potential to control phytoplankton blooms. Aquat Microb Ecol 20:167-181

Montagnes DJS, Weisse T (2000) Fluctuating temperatures affect growth and production rates of planktonic ciliates. Aquat Microb Ecol 21:97-102

Montagnes DJS, Berges JA, Harrison PJ, Taylor FJM (1994) Estimating carbon, nitrogen, protein, and chlorophyll from volume in marine-phytoplankton. Limnol Oceanogr 39: 1044-1060

Montagnes DJS, Kimmance SA, Atkinson D (2003) Using $Q_{10}$ : can growth rates increase linearly with temperature? Aquat Microb Ecol 32:307-313

Orcutt JD, Porter KG (1984) The synergistic effects of temperature and food concentration on life-history parameters of Daphnia. Oecologia 63:300-306

Rassoulzadegan F (1982) Dependence of grazing rate, gross growth efficiency and food size range on temperature in a pelagic oligotrichous ciliate Lohmanniella spiralis Leeg., fed on naturally occurring particulate matter. Ann Inst Océanogr NS 58:177-184

Rogerson A (1981) The ecological energetics of Amoeba proteus (Protozoa). Hydrobiologia 85:117-128

Sherr BF, Sherr EB, Berman T (1983) Growth, grazing and ammonia excretion rates of a heterotrophic microflagellate fed with four species of bacteria. Appl Environ Microbiol 45:1196-1201

Stelzer CP (1998) Population growth in planktonic rotifers. Does temperature shift the competitive advantage for different species? Hydrobiologia 388:349-353

Straile D (1997) Gross growth efficiencies of protozoan and

Editorial responsibility: Robert Sanders, Philadelphia, Pennsylvania, USA metazoan zooplankton and their dependence on food concentration, predator-prey weight ratio, and taxonomic group. Limnol Oceanogr 42:1375-1385

Strom SL (1991) Growth and grazing rates of the herbivorous dinoflagellate Gymnodinium sp. from the open sub-arctic Pacific Ocean. Mar Ecol Prog Ser 78:103-113

Strom SL, Buskey EJ (1993) Feeding, growth, and behaviour of the thecate heterotrophic dinoflagellate Oblea rotunda. Limnol Oceanogr 38:965-977

Thébault JM (1985) Étude expérimentale de la nutrition d'un copépode commun (Temora stylifera Dana). Effets de la température et de la concentration de nourriture. J Exp Mar Biol Ecol 93:223-234

Valiela I (1995) Marine ecological processes. Springer-Verlag, New York

Verity PG (1985) Grazing, respiration, excretion, and growth rates of tintinnids. Limnol Oceanogr 30:1268-1282

Weisse T, Stadler P, Lindstrom ES, Kimmance SA, Montagnes DJS (2002) Interactive effect of temperature and food concentration on growth rate: a test case using the small freshwater ciliate Urotricha farcta. Limnol Oceanogr 47 : $1447-1455$

Wolfe GV (2000) The chemical defense ecology of marine unicellular plankton: constraints, mechanisms, and impacts. Biol Bull 198:225-244

Wolfe GV, Steinke M (1996) Grazing-activated production of dimethyl sulfide (DMS) by two clones of Emiliania huxleyi. Limnol Oceanogr 41:1151-1160

Wolfe GV, Steinke M, Kirst GO (1997) Grazing-activated chemical defense in a unicellular marine alga. Nature 387 : 894-897

Submitted: May 20, 2005; Accepted: October 17, 2005 Proofs received from author(s): January 25, 2006 